\title{
斜入射軽イオンスパッタリングの角度分布
}

\author{
山 村 泰道, 滝 口敬 \\ (岡山理科大学理学部) \\ 李之傑* \\ （内蒙古民族師範学院） \\ (1991年 7 月11日受理)
}

\section{Angular Distributions of Sputtered Atoms at Oblique Incidence of Low-Energy Light-Ion}

Yasunori Yamamura, Takeshi Takiguchi and Zhijie Li ${ }^{*}$

(Received July 11, 1991)

\begin{abstract}
The bombarding angle dependence and the angular distributions of the light-ion sputtering have been investigated by the computer simulation and the direct-knock-out model, where the $\mathrm{Ni}$ target is bombarded by $450 \mathrm{eV}$ and $1 \mathrm{keV} \mathrm{H}$. As a computer simulation code we adopted the ACAT code. The main feature of the light-ion sputtering at oblique incidence is found to be described by the direct-knock-out process. The interatomic potential is an important factor for the bombarding-angle dependence of the light-ion sputtering. In the case of $1 \mathrm{keV} \mathrm{H}^{+} \rightarrow \mathrm{Ni}$, the ACAT results of the bombarding-angle dependence and the angular distribution are in good agreements with experiments. The experimental angular distributions of $450 \mathrm{eV} \mathrm{H}{ }^{+} \rightarrow \mathrm{Ni}$ at oblique incidence $\left(>80^{\circ}\right)$ cannot be explained by both the ACAT simulation and the directknock-out model, and seems to be much influenced by the surface roughness.
\end{abstract}

\section{Keywords :}

light-ion sputtering, bombarding-angle dependence angular distrbution of sputtered atom, direct-knock-out model, computer simulation,

軽イオンスパッタリング収量の入射角依存性とスパッター原子の角度分布をモンテカルロシミュレーショ ン・コード ACAT と簡単なはじきだしモデルを用いて計算し, 実験と比較検討した。軽イオンとしては軽水

素，標的物質としては $\mathrm{Ni}$ を選び，入射エネルギーとしては $450 \mathrm{eV}$ と $1 \mathrm{keV}$ を用いた。

Okayama University of Science, Okayama 700.

* Permanent address : Inner Mongolia Normal University, Physics Division, 028043, China. 
軽イオンが斜めに照射された場合のスパッタリング現象の主たる模相ははじきだしモデルで説明できる. スパッタリング収量の入射角依存性については 2 体間ポテンシャルを適切に選べば実験を再現できることが わかった，直接はじきだしモデルによる角度分布は非常にはっきりした優先放出角を持ち，その理論值は $1 \mathrm{keV}$ の場合, シミュレーションの值, 実験值とょい一致をみた。しかしながら, 低エネルギーの $450 \mathrm{eV} の$ 場合には ACATによる角度分布も直接はじきだし過程による角度分布もともに実験よりはるかに大きい優先 放出角を持ち，実験では表面荒さの影響を強く受けている可能性がある.

\section{1. はじめに}

プラズマ・壁相互作用（PWI）に関する種々の問題の中でも入射する軽イオンによる第一壁やダイバータ 板の物理スパッタリングによる損耗やスパッターされた不純物の炉心での蓄積等は, 今日, 核融合炉研究の 中心的課題の 1 つである. 特にダイバー夕板は熱応力を軽減させるため, 磁力線に対して $85^{\circ}$ 以上の角度を 持たしている場合がある。このことは軽イオンスパッタリング収量の入射角依存性のより正確な知見が要求 されることを意味している，また，不純物の炉心への混入という観点からみれば，スパッター原子のエネル ギー分布や角度分布の知見も必要となってくる。

軽イオンによるスパッタリングは中重イオンの場合と異なって入射イオンにより表面近傍に形成される衝 突カスケードによるのではなく, 固体内部で反射された軽イオンが表面から出る時に表面近傍の標的原子を 吒きだすことによる ${ }^{1,2)}$ ，すなわち，軽イオンのスパッタリング収量は反射係数と反射イオンによる表面近 傍に付与されたエネルギーに比例することになる3）.

スパッタリング収量の入射角依存性に関する理論は1969年 Sigmundによって与えられた。すなわち， $Y(\theta) / Y(0)=\cos ^{-f} \theta(f=1 \sim 2)^{4)}$. 一方, 山村等は1983年, 種々の実験デー夕を解析し次の半実験式を提 案した ${ }^{5)}$. すなわち, $Y(\theta) / Y(\theta)=X^{f} \exp [-\Sigma(X-1)], こ こ に X=1 / \cos \theta$. スパッタリング収量の入射 角依存性に関する実験データは1959年の Wehner の実験6) 以来多くの報告があるが軽水, 重水イオンに関す るデータは1979年の Bay and Bohdansky の論文 ${ }^{7)}$ が最初で, 以降, 核融合炬におけるプラズマ・壁相互作 用という観点から主として Max Plank 研究所（Garching）を中心に測定データが報告された ${ }^{8,9)}$. 最近, Haasz 等によりグラファイトに関する軽イオンによるスパッタリング収量の入射角依存性の実験 ${ }^{10)}$ や Roth 等による低エネルギー(数百 $\mathrm{eV}$ ) 軽イオンによるスパッタリング収量の入射角依存性の実験の報告がある ${ }^{11)}$.

微分スパッタリング収量, すなわち, 角度分布とエネルギー分布に関する理論的報告 ${ }^{12,13)}$, また， シ ミュレーションによる解析 ${ }^{14-17)}$, 実験的報告は数多くあるが, 軽イオンによるスパッ夕ー原子の角度分布 に関して言えば，やはり，Max Plank 研究所（Garching）を中心に測定データが報告されている ${ }^{9,18,19)}$. しかしながら，軽イオンによるスパッター原子のエネルギー分布に関してあまり報告例がない20,21). 本報告では軽イオンスパッタリング収量の入射角依存性とスパッター原子の角度分布をモンテカルロシ ミュレーション・コード ACAT と簡単なはじきだしモデルを用いて, 計算し, 実験と比較検討することによ 
りそれらの量に及ぼす 2 体間ポテンシャルの影響について考察する. 軽イオンとしては軽水素, 標的物質と しては $\mathrm{Ni}$ を，入射エネルギーとしては $450 \mathrm{eV}$ と $1 \mathrm{keV}$ 選んだ。

\section{2. 直接はじきだし過程}

軽イオンの入射角が小さいときは，軽イオンによるスパッタリングは中重イオンの場合と異なって入射イ オンにより表面近傍に形成される衝突カスケードによるのではなく，固体内部で反射された軽イオンが表面 から出る時に表面近傍の標的原子を吅きだすことによる，軽イオンを十分斜めから入射させた場合，入射軽 イオンと表面原子とのはじきだし過程が重要となる。はじきだし過程は図 1 に示すように大きく分けて直接

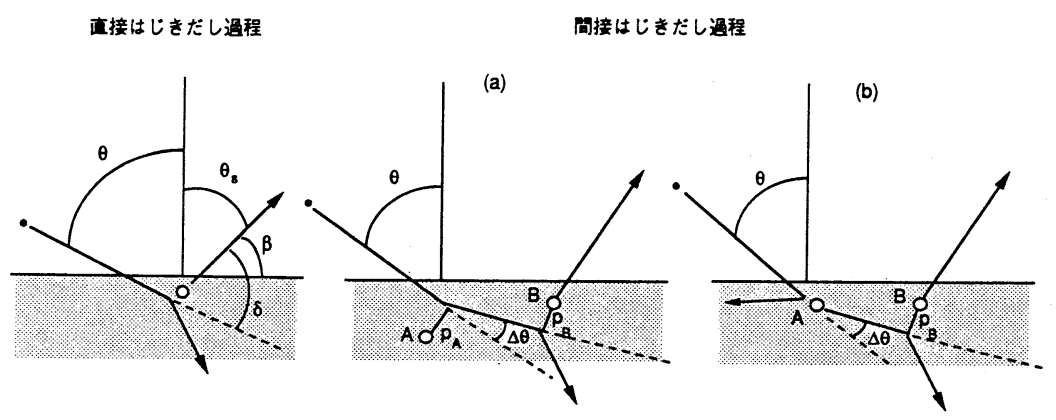

図 1. 斜入射軽イオンスパッタリングのはじきだし過程.

過程と間接過程があり，入射角が小さいに場合には間接はじきだし過程しか起こりえず，大きい場合には直 接はじきだし過程が主である。また，間接はじきだし過程には 2 種類の過程が考えられるが図における間接 はじきだし過程(b)は確率的に低く無視できるであろう，以後の議論においては間接はじきだし過程と言え ば間接はじきだし過程 $(\mathrm{a})$ を意味することにする。

図 1 における直接はじきだし過程は入射角 $\theta$ が約 $70^{\circ}$ 以上すれすれに照射した場合に重要な過程で，一 方，間接じきだし過程はそれにより小さい場合でも起こる，間接じきだし過程は直接はじきだし過程の変形 であって表面近傍の他の原子により入射イオンが散乱された後, はじきだし過程により原子がスパッターさ れる ${ }^{22,23)}$.

まず，理論的に取り扱いやすい直接はじきだし過程によるスパッタリングを考える．スパッター原子の飛 び出す条件として面に対して垂直な表面ポテンシャルを仮定すると直接はじきだし過程により反跳原子が飛 び出すことが出きるためには反跳角 $\delta$ は次の条件を満足しなければならない.

$$
\cos ^{2} \delta \cos ^{2}(\theta+\delta) \geq q^{2}
$$


核融合研究 第66巻第 3 号 1991年 9 月

ここに， $q=\left(U_{\mathrm{s}} / \gamma E\right)^{1 / 2}$ で， $E$ は入射エネルギー， $U_{\mathrm{s}}$ は表面結合エネルギーで，また， $\gamma$ は

$$
\gamma=\frac{4 M_{1} M_{2}}{\left(M_{1}+M_{2}\right)^{2}}
$$

（2）式における $M_{1}, M_{2}$ は入射イオンと標的原子の質量数である。（1）方程式の解として

$$
\delta_{1} \leq \delta \leq \delta_{2}
$$

を得る ${ }^{22)}$ 。ここに，

$$
\begin{aligned}
& \delta_{1}=\frac{\pi-\theta-\cos ^{-1}(\cos \theta+2 q)}{2} \\
& \delta_{2}=\frac{\pi-\theta+\cos ^{-1}(\cos \theta+2 q)}{2}
\end{aligned}
$$

$q$ が十分小さいと $\delta_{1}, \delta_{2}$ は簡単な表式で表 されるがここでは比較的低エネルギ一軽イオ ンを取り扱うため数值計算した結果を入射角 の関数として図 2 に示す. $450 \mathrm{eVH}^{+} \rightarrow \mathrm{Ni}$ の 場合（ $q=0.385 ）$ には76. $8^{\circ}$ から直接はじき だし過程が始まり，1 $\mathrm{keVH}^{+} \rightarrow \mathrm{Ni}$ の場合 $(q$ $=0.259)$ には $61.2^{\circ}$ から直接はじきだし過 程が始まる。

反跳角 $\delta$ は重心系の散乱角 $\Theta$ と $\delta=(\pi-$ @）/2の関係を通して散乱における衝突係数 $p$ に直接関係している。すなわち, 散乱ポテ ンシャルをべき乗近似を採用すると衝突係数 と反跳角 $\delta$ の間には

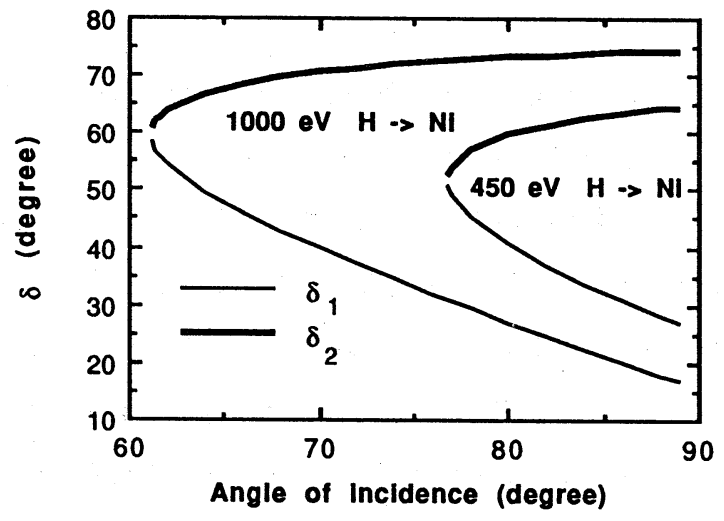

図2. $450 \mathrm{eVH}^{+} \rightarrow \mathrm{Ni}$ と $1 \mathrm{keVH}^{+} \rightarrow \mathrm{Ni}$ において 直接はじきだし過程が可能な反跳角 $\delta$ の 領域の入射角依存性.

$$
2 \varepsilon \cot \delta=\left(k_{\mathrm{m}} \frac{a}{p}\right)^{1 / m}
$$


の関係が近似的に存在する。ここに，上式における $m$ は散乱ポテンシャルのべき乗近似のべきである。し たがって， $\delta_{1} ， \delta_{2}$ に対応する衝突係数を $p_{1}, p_{2}$ とすると次式を満足しなければならない.

$$
p_{1}<p<p_{2}<R_{0} \cos \theta
$$

ここに， $R_{0}$ は標的の平均格子定数である，不パッタリング収量の入射角依存性を入射角に対してプロットす ると通常， $\theta=70^{\circ} \sim 80^{\circ}$ の近傍にピークを持つ，その収量の最大值を与える入射角を $\theta_{\mathrm{opt}}$ とすると，そ の角度は $p_{2}=R_{0} \cos \theta$ に対応している，qが十分小さい時には次のような簡単な表式で表される.

$$
\theta_{\mathrm{opt}}=90^{\circ}-57.3 \frac{a}{R_{0}} \sqrt{\frac{1}{\varepsilon q}}
$$

ここにおいて，(6) 式の $m=1 / 2 を$ 用いた。

次に，スパッター原子の飛び出す条件として面に対して垂直な表面ポテンシャルを仮定してと直接はじき だし過程によるスパッター原子の角度分布 $Y\left(\theta_{\mathrm{s}}\right)$ について考察する。簡単な計算の後, 反跳角 $\delta$ と出射角 $\theta_{\mathrm{s}}$ の間には次の関係があることがわかる。すなわち,

$$
\sin ^{2} \theta_{s}=\frac{\cos ^{2} \delta \sin ^{2}(\theta+\delta)}{\cos ^{2} \delta-q^{2}}
$$

ここで, 反跳角 $\delta$ が衝突係数 $p$ の関数であることを考えれば，直接はじきだし過程によるスパッター原子 の角度分布 $Y\left(\theta_{\mathrm{s}}\right)$ はイオンビームが一様であるので形式的に

$$
Y\left(\theta_{\mathrm{s}}\right) \propto\left|\frac{\mathrm{d} \theta_{\mathrm{s}}}{\mathrm{d} p}\right|^{-1}
$$

で与えられ，散乱に関してやはりべき乗を仮定すれば角度分布 $Y\left(\theta_{\mathrm{s}}\right)$ は次式となる。

$$
Y\left(\theta_{\mathrm{s}}\right) \propto\left|\frac{\sin 2 \theta_{\mathrm{s}}\left(\cos ^{2} \delta-q^{2}\right)^{2} \tan ^{1-m} \delta}{\cos ^{3} \delta \sin (\theta+\delta)\left\{\cos ^{3} \delta \cos (\theta+\delta)-q^{2} \cos (\theta+2 \delta)\right\}}\right|
$$

したがって，直接はじきだし過程によるスパッタ一原子の角度分布の優先放出角 $\theta$ pre は次の超越方程式の 
解として与えられた反跳角 $\delta_{\mathrm{m}}$ を（9）式に代入すればよい.

$$
\left\{\cos ^{3} \delta_{\mathrm{m}} \cos \left(\theta+\delta_{\mathrm{m}}\right)-q^{2} \cos \left(\theta+2 \delta_{\mathrm{m}}\right)\right\}=0
$$

図 3 は数值計算した優先放出角 $\theta_{\mathrm{pre}}$ と $\delta_{\mathrm{m}}$ を入射角の関数としてプロットしている。また，図 4 には

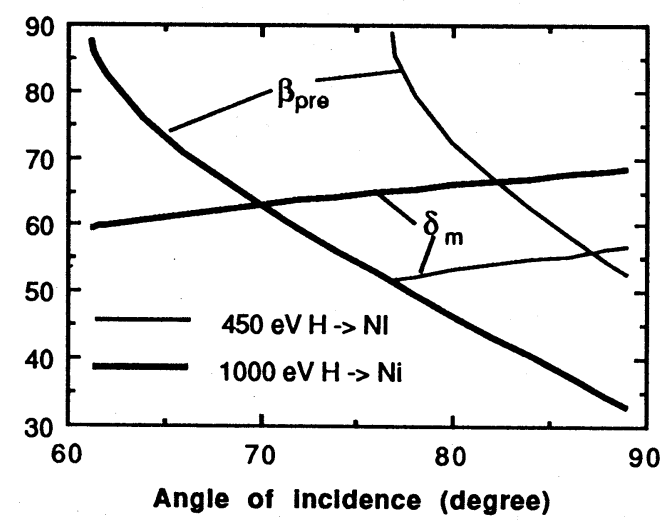

図 3. $450 \mathrm{eVH}^{+} \rightarrow \mathrm{Ni}$ と $1 \mathrm{keVH}^{+} \rightarrow \mathrm{Ni}$ における直 接はじきだし過程による優先放出角とそ れを与える反跳角 $\delta_{m}$ の入射角依存性.

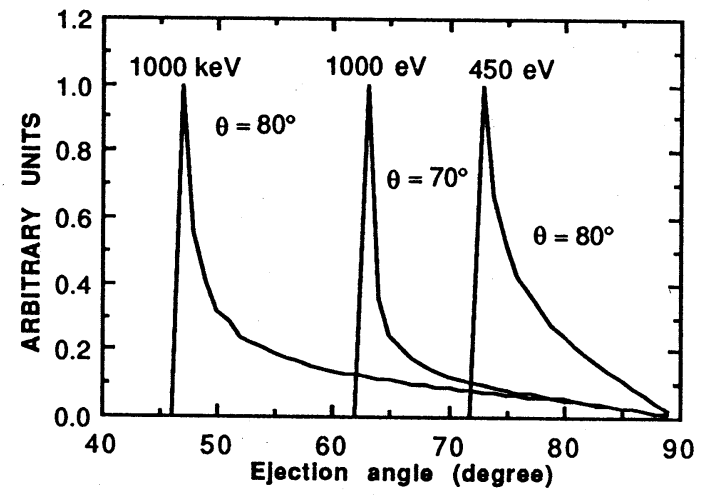

図 4. $450 \mathrm{eVH}^{+} \rightarrow \mathrm{Ni}\left(\theta=80^{\circ}\right)$ と $1 \mathrm{keVH}^{+} \rightarrow \mathrm{Ni}$ $\left(\theta=70^{\circ}, 80^{\circ}\right)$ の場合の直接はじきだ し過程による角度分布.

（11）式を用いた角度分布 $Y\left(\theta_{\mathrm{s}}\right)$ の計算結果をしめしてある. 図には $450 \mathrm{eVH}^{+} \rightarrow \mathrm{Ni}\left(\theta=80^{\circ}\right)$ と $1000 \mathrm{eVH}^{+}$ $\rightarrow \mathrm{Ni}\left(\theta=70^{\circ}\right.$ と $\left.\theta=80^{\circ}\right)$ の場合についての結果を示した。この図からわかるように直接はじきだし過程に よるスパッター原子の角度分布は鋭いピークをもつ。

優先放出角 $\theta_{\mathrm{pre}}$ に関する簡単な表式は $q$ が小さい時限り $\delta_{\mathrm{m}} \sim \delta_{2}$ がいえるので

$$
\theta_{\text {pre }}=\sin ^{-1} \sqrt{(\cos \theta+q)(\cos \theta+2 q)}
$$

\section{と言う近似表式を得る。}

間接はじきだし過程は 2 個以上の表面原子が関与するが, 図 1 において A 原子により $\Delta \theta$ だけ入射角が傾 いて B 原子に入射することに対応するので，およそ次の条件が成立すれば $\mathrm{B}$ 原子はスパッ夕ーされる。

$$
p_{1}(\theta+\Delta \theta) \leq p_{\mathrm{B}} \leq p_{2}(\theta+\Delta \theta)
$$

ここに, B 原子に対する衝突係数 $p_{\mathrm{B}}$ は次式で与えられる.

$$
p_{\mathrm{B}}=\cos (\theta+\Delta \theta) R_{0}-p_{\mathrm{A}} \cos \Delta \theta
$$


ゆえに間接はじきだし過程は直接はじきだし過程より小さい入射角で表面原子がスパッターされる機構であ り， $\Delta \theta$ は $0^{\circ}$ から $90^{\circ}-\theta$ まで許されるので当然, 間接はじきだし過程による角度分布 $Y\left(\theta_{\mathrm{s}}\right)$ は図 4 に示 される角度分布を重ね合わせた分布となり直接はじきだし過程の分布と比べて幅広くなることが予想される。

\section{3. 計算結果と議論}

物理スパッタリングを計算機にてシミュレーションすることは多くの研究者によってなされてきたが，中 でも Max Plank 研究所 (Garching) の Eckstein 等は実験グループとタイアップしてTRIM コードを用い て多くの研究成果を報告している ${ }^{24,25)}$ 。しかしながら， $\theta>70^{\circ}$ の場合には，まだ，必ずしも良い一致を みない場合がある。本報告においては山村等によって開発されたACAT コードを用いてシミュレーションを 行う. ACATコードは他のモンテカルロ・コードと異なって平均自由行程の概念を用いてなく, 図 5 のよう に固定を一辺 $R_{0}$ の単位立方格子に分け，その中に標的原子が無作為に分布していると仮定している．本 来, 平均自由行程を定義しぬくい表面近傍のスパッタリング等の現象のシミュレーションに適していると期 待できる，ACATコードの詳細は既に他の論文に発表しているので本計算に必要な点だけを述べる.

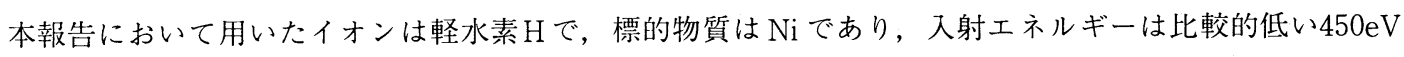
と $1000 \mathrm{eV}$ を選んだ，水素原子の固体中での電子的エネルギー損失はZiegler のテーブルの半実験式と数值 を用いて評価した。 2 体間ポテンシャルとしては, Wilsonの Kr-Cポテンシャル, Moliere ポテンシャル を採用しているが, 遮蔽半径 $a$ の值としては通常に $0.100 \AA$ を用いる. 図 6 は垂直入射 $\left(\theta=0^{\circ}\right)$ の場合

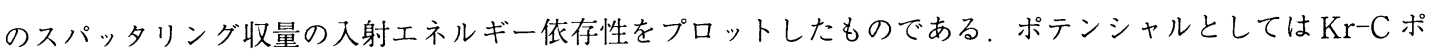
テンシャルを用いた，実験は旧プラ研グループにより提唱されさた半実験式の結果である。ACAT 值は実験 と良い一致を示している，垂直入射の場合のスパッタリング収量のポテンシャル依存性は殆どない，すなわ ち, $450 \mathrm{eVH}^{+}$に対しては $Y(\mathrm{Kr}-\mathrm{C})=0.011, \quad Y($ Moliere $)=0.011$ である.

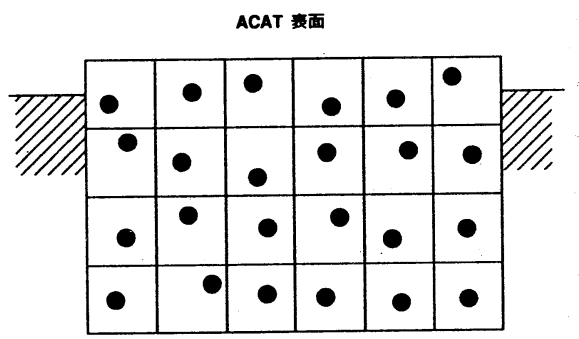

図 5.ACAT コードにおける非晶系固体の シミュレーション.

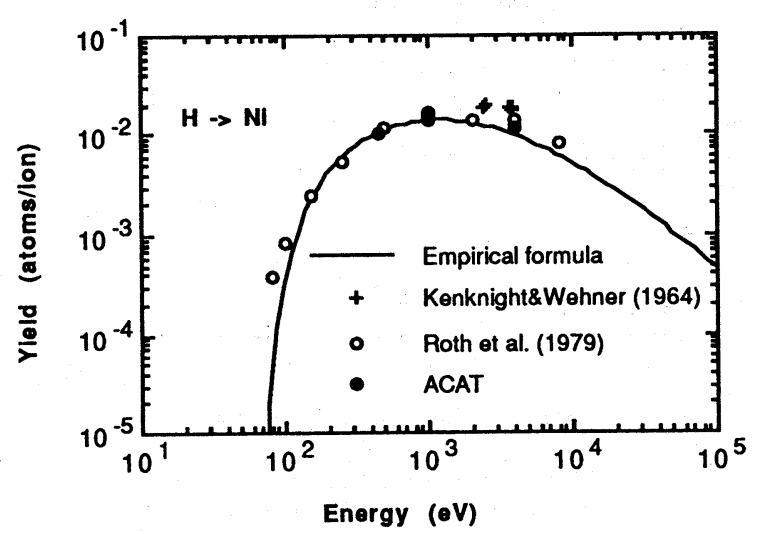

図6. 垂直入射の場合の $\mathrm{H}^{+} \rightarrow \mathrm{Ni}$ のスパッタ リング収量 (atoms/ion) のエネルギー 依存性. ただし, ACATのポテンシャル は $\mathrm{Kr}-\mathrm{C}(a=0.100 \dot{A})$ である. 
垂直入射の場合のスパッタリングは中重イオンの場合と異なって入射イオンにより表面近傍に形成される 衝突カスケードによるのではなく, 図 7 のように固体内部で反射された軽イオンが表面から出る時に表面近 傍の標的原子を吒きだすことによる，すなわち，軽イオンのスパッタリング収量は反射係数と密接な関係が ある。本報告では図 7 のような過程をランダム過程と呼ぼう。図 7 に打けるd は はスパッターを引き起こした 後方散乱イオンの最大侵入深さとして定義される量で，dに注目するとランダム過程かはじきだ過程によ るのかの識別がつく.

\section{1 軽イオンスパッタリング収量の入射角依存 性}

図 8，9，10は4keV，1keV，450 $\mathrm{eVH}^{+}$イオン を $\mathrm{Ni}$ ターゲットに照射した場合のスパッタリ ング収量の入射角依存性をプロットしたもので ある、図においては実験と ACAT $(\mathrm{Kr}-\mathrm{C})$ による 計算結果を比較してある。ここに, 遮蔽半径 $a$ の值は $0.100 \AA$ である。図における実線は次の 半実験式を用いて実験值をべストフィットした ものである。すなわち，

$$
Y(\theta) / Y(0)=T^{f} \exp [-\Sigma(X-1)]
$$

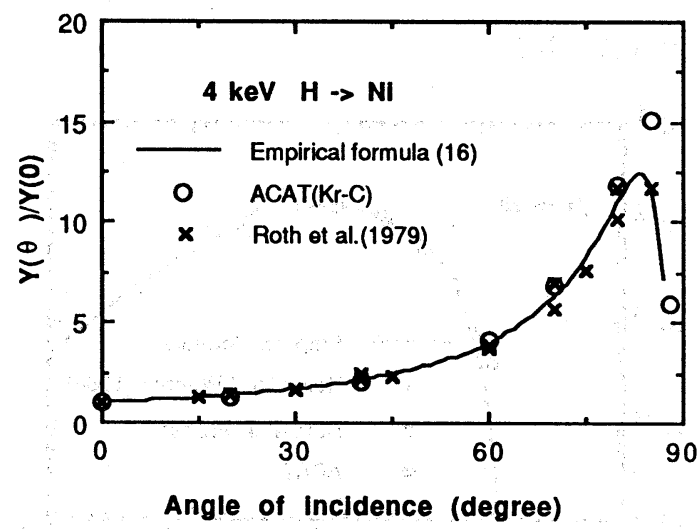

図 8.4keVH ${ }^{+} \rightarrow \mathrm{Ni}$ の場合の実験ならびに ACAT シミュレーション $(\mathrm{Kr}-\mathrm{C}, a=0.100 \AA)$ の規 格化されたスパッタリング収量 $Y(\theta) / Y(0)$ の入射角依存性. 図における実線は半実験 式(16)であり，各々のパラメターは表 1 を 参照.
軽イオンスパッタリング機掅

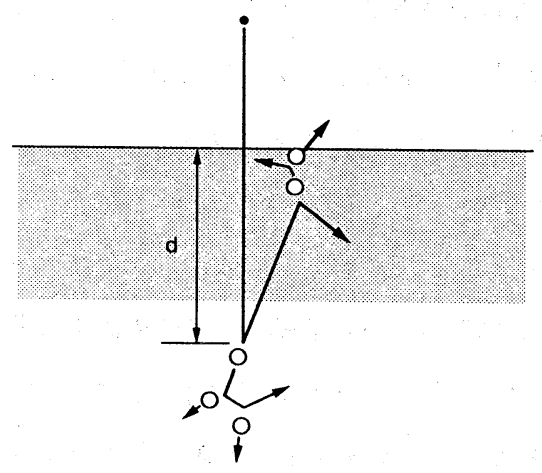

図 7.軽イオンスパッタリングの機構の特徵。図に おいてはdはスパッターを引き起こした後方 散乱イオンの最大侵入深さである.

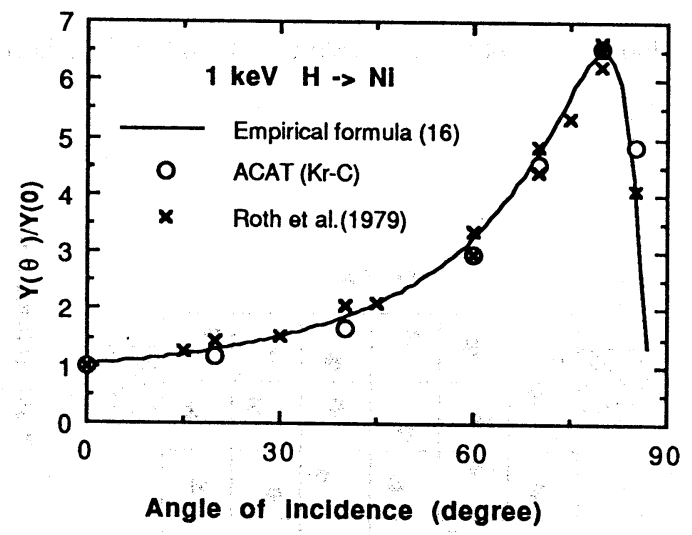

図 9. $1 \mathrm{keVH}^{+} \rightarrow \mathrm{Ni}$ の場合の実験ならびに ACAT シミュレーション $(\mathrm{Kr}-\mathrm{C}, a=0.100 \AA)$ の規 格化されたスパッタリング収量 $Y(\theta) / Y(0)$ の入射角依存性：図における実線は半実験 式(16)であり，各々のパラメターは表 1 を 参照. 
ここに, $T=(1+A \sin \theta) / \cos \theta, \quad X=1 / \cos$ $\theta$ ．Tに含まれる $\sin \theta$ の項ははじきだし過 程の寄与，すなわち， $p_{2}{ }^{2}$ に対応している. それぞれの実験值に対する最適值は表 1 に示 してある。表1からわかるとおりエネルギー が増すにつれてはじきだし過程の寄与が大き くなっている。

図 8，9，10を見て気付くことは $4 \mathrm{keV，}$ $1 \mathrm{keV}$ については実験值と ACAT $\left(\mathrm{Kr}^{-} \mathrm{C}\right)$ の値 の一致は満足べきものである。しかしながら， $450 \mathrm{eV}$ については実験値と ACAT $(\mathrm{Kr}-\mathrm{C})$ の

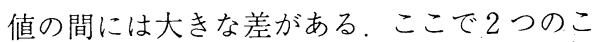
とを指摘しなければならない。まず，ピーク 近傍の $Y(\theta) / Y(0)$ 值が実験值に比べて大き いこと，また, ACAT データの $\theta_{\mathrm{opt}}$ の值が 実験値に比べて大きい方にずれていることで ある。これら 3 つの図からいくつかのことが 考えられる。まず, $1 \mathrm{keV}, 4 \mathrm{keV}$ の場合に比

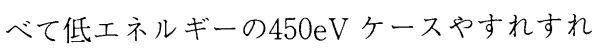
の入射角の場合には表面一層の原子との相互 作用が大きく，表面の粗さの影響を検討する 必要がある。ささらに, ACAT データの $\theta \mathrm{opt}$ の 值が実験值に比べて大きい方にずれているこ とは 2 体間ポテンシャルが $\mathrm{KR}-\mathrm{C}(a=0.10 \AA)$ より遠距離まで及んでいる可能性がある.

まず， 2 体間ポテンシャルのスパッタリン グ収量の入射角依存性に及ばす影響を知るた めに Moliere ポテンシャル $(a=0.100 \AA)$ と Moliere ポテンシャルでも遮蔽定数を変えた 場合，すなわち， $a=0.116 \AA$ の結果を図 11 に示した。図において Moliere-1 は $a=$ $0.100 \AA$ に対応し, Moliere-2は $a=0.116 \AA$

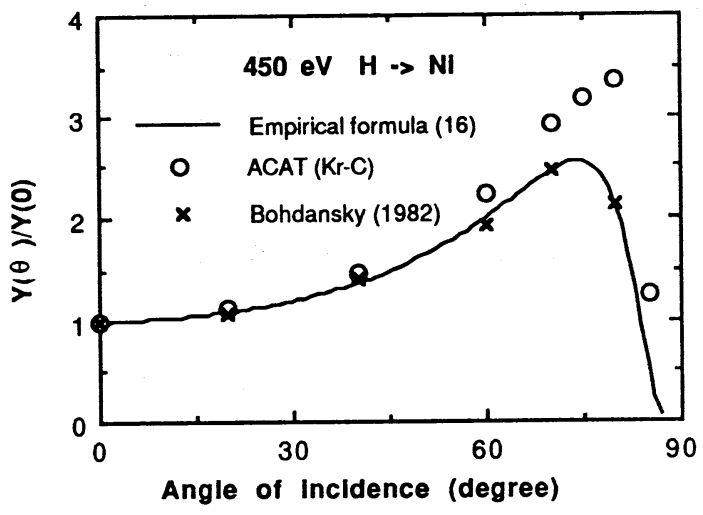

図10.450eVH ${ }^{+} \rightarrow \mathrm{Ni}$ の場合の実験ならびに ACAT シミュレーション $(\mathrm{Kr}-\mathrm{C}, a=0.100 \AA)$ の規 格化されたスパッタリング収量 $Y(\theta) / Y(0)$ の入射角依存性. 図における実線は半実験式 (16)であり，各々のパラメターは表1を参照.

表1. $\mathrm{H}^{+} \rightarrow \mathrm{Ni}$ 軽イオンスパッタリング 収量の入射角依存性の実験值に対 する半実験公式（16）の最適値

\begin{tabular}{|c|c|c|c|}
\hline Energy & $A$ & $f$ & $\Sigma$ \\
\hline $450 \mathrm{eV}$ & 0.014 & 1.57 & 0.423 \\
$1 \mathrm{keV}$ & 0.314 & 1.53 & 0.258 \\
$4 \mathrm{keV}$ & 0.459 & 1.50 & 0.167 \\
\hline
\end{tabular}

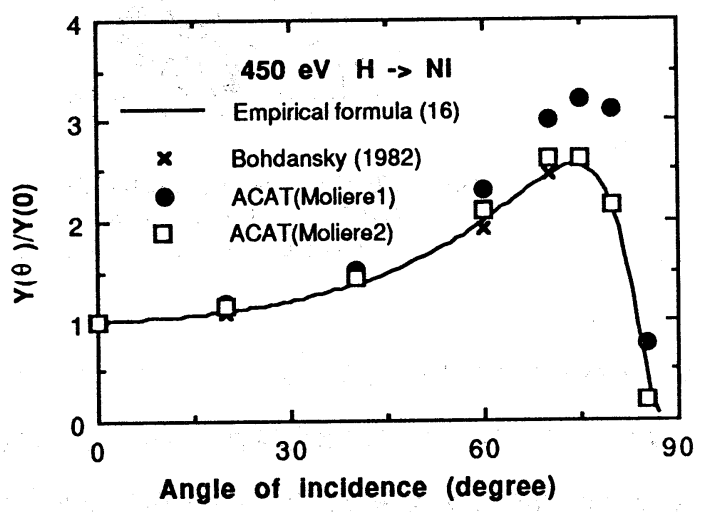

図11. $450 \mathrm{eVH}^{+} \rightarrow \mathrm{Ni}$ の場合の実験ならびに ACAT シミュレーション(Moliere)の規格化された スパッタリング収量 $Y(\theta) / Y(0)$ の入射角依 存性. 図における実線は半実験式(16)であり, 各々のパラメーターは表 1 を参照. 
に対応している．Moliere-2と実験値との一致はよ い.なお, Moliere-2ポテンシャルの垂直入射の収 量は $Y($ Moliere-2) $=0.014$ である（表 2 参照）。

\section{2 軽イオンによるスパッター原子の角度分布}

ACAT シミュレーションによる角度分布を入射角 表 2 .いろいろな 2 体間ポテンシャルに対する $450 \mathrm{eVH}^{+} \rightarrow \mathrm{Ni}$ のスパッタリング収量.

が $0^{\circ}, 60^{\circ}, 80^{\circ}$ の場合について図 12 に示した。

\begin{tabular}{|l|c|c|c|}
\hline $\begin{array}{l}\text { ポテン } \\
\text { シャル }\end{array}$ & $0^{\circ}$ & $60^{\circ}$ & $80^{\circ}$ \\
\hline $\mathrm{Kr}-\mathrm{C}(a=0.100 \AA \dot{A})$ & 0.010 & 0.024 & 0.037 \\
Moliere $(a=0.100 \dot{A})$ & 0.011 & 0.024 & 0.033 \\
Moliere $(a=0.116 \dot{A})$ & 0.014 & 0.030 & 0.030 \\
\hline
\end{tabular}

$\mathbf{H} \rightarrow \mathbf{N i}$
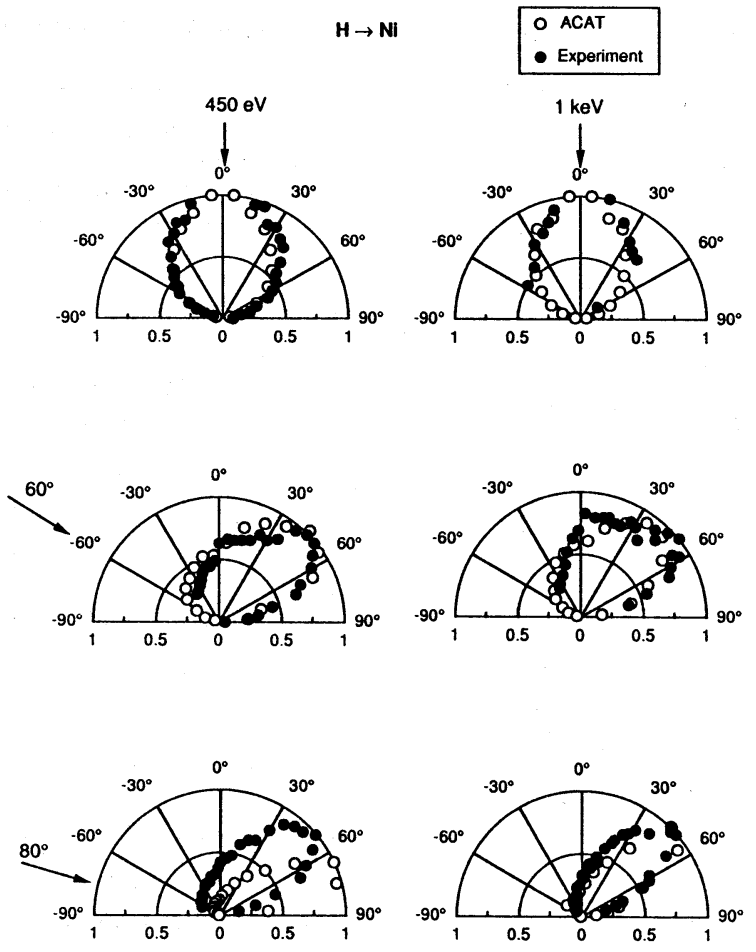

図12. $450 \mathrm{eVH}^{+} \rightarrow \mathrm{Ni}$ ならびに1 $\mathrm{keVH}^{+} \rightarrow \mathrm{Ni}$ の場合における実験の角度分布と ACAT シミュレーション $(\mathrm{Kr}-\mathrm{C}, a=0.100 \AA)$ の角度分布の比較. 入射角 として $0^{\circ}, 60^{\circ}, 80^{\circ}$ を選んでいる.

軽イオンスパッタリングの機構から考えていくらエネルギーが低くても角度分布が under-cosine 分布を取 ることはない．図12において○は実験值であり，E=450eVの実験は Bohdansky 等のものであり，一方， $E$ $=1 \mathrm{keV}$ それは Roth 等の実験である. $E=450 \mathrm{eV} て ゙ \theta=80^{\circ}$ のケースを除いて ACAT シミュレーションと実 験值の一致はよい。 $\theta=60^{\circ}$ では，はじきだし過程によらないので分布は巾広い形である。 $E=450 \mathrm{eV} て ゙ ~ \theta$ $=80^{\circ}$ のケースは後に詳しく議論することにしょう.

角度分布へ与える 2 体間ポテンシャルの影響をみるために図13に $\mathrm{Kr}-\mathrm{C} （ a=0.100 \AA)$ と Moliere-2 $(a=$ 
$0.116 \AA)$ を用いてシミュレーションした結果を $\theta=60^{\circ}$ と $\theta=80^{\circ}$ の場合について示した。表 2 に示したようにスパッタリング収量は異なる が最大値を 1 として規格化した分布はあまり変 わらない。特に $\theta=80^{\circ}$ の場合に関しては同じ ように巾の狭い分布をしている。これは直接は じきだし過程の特徵であり，直接はじきだし過 程による角度分布はあまり 2 体間ポテンシャル 依存性がない。すなわち, 図 4 の分布はポテン シャルに関係なく決まっている。しかしながら， $E=450 \mathrm{eV}$ で $\theta=80^{\circ}$ の場合, $\operatorname{Kr}-\mathrm{C}(a=0.100$ Å) と Moliere-2 $(a=0.116 \AA)$ にる優先放出 角は約 $70^{\circ}$ であり，実験の約 $45^{\circ}$ とかなり差が ある。

はじきだし過程の分布に対する寄与の割合を 知るために図 7 で定義されたスパッターを引き 起こした後方散乱イオンの最大侵入深さ $d$ をパ ラメーターとして分布を整理して図14，15に示 した。眓14は450eV の場合であり，図15は1 keV の場合である。図において $0<d<2.5 \AA$ は $\mathrm{Ni}$ の平均定数 $R_{0}$ が $2.22 \AA$ であることを考えれば， はじきだし過程である。 $\theta=60^{\circ}$ の場合は理論 的にいっても間接はじきだし過程であり， $\theta=$ 80は直接はじきだし過程であることが言える。 $E=450 \mathrm{eV}$ で $\theta=60^{\circ}$ ではランダム過程がかな りの寄与をしており，とくに後方にスパッター される原子はランダム過程によることが明らか である。このことは図 15 の $E=1 \mathrm{keV}$ で $\theta=60^{\circ}$ のケースではより顕著である.

図14は450eVで $\theta=80^{\circ}$ の場合には表面一層 でスパッタリングが起こっていること意味して おり，当然表面の状態に強く依存していること
$450 \mathrm{eVH} \rightarrow \mathrm{Ni}$

○ $\mathrm{Kr}-\mathrm{C}(\mathrm{a}=0.100 \dot{A})$
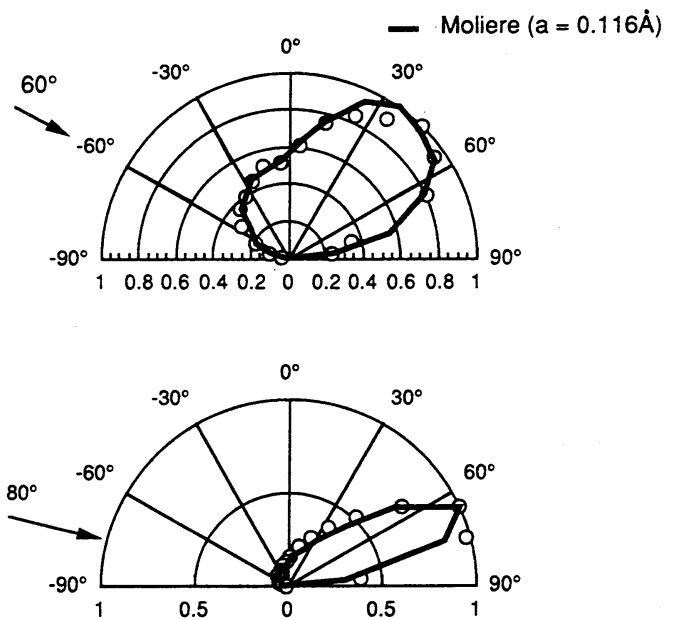

図13. $450 \mathrm{eVH}^{+} \rightarrow \mathrm{Ni}\left(60^{\circ}, 80^{\circ}\right)$ の場合における ACAT シミュレーションの角度分布. $\mathrm{Kr}-\mathrm{C}(a=0.100 \dot{A})$ と Moliere-2 $(a=0.116 \AA)$ の比較.
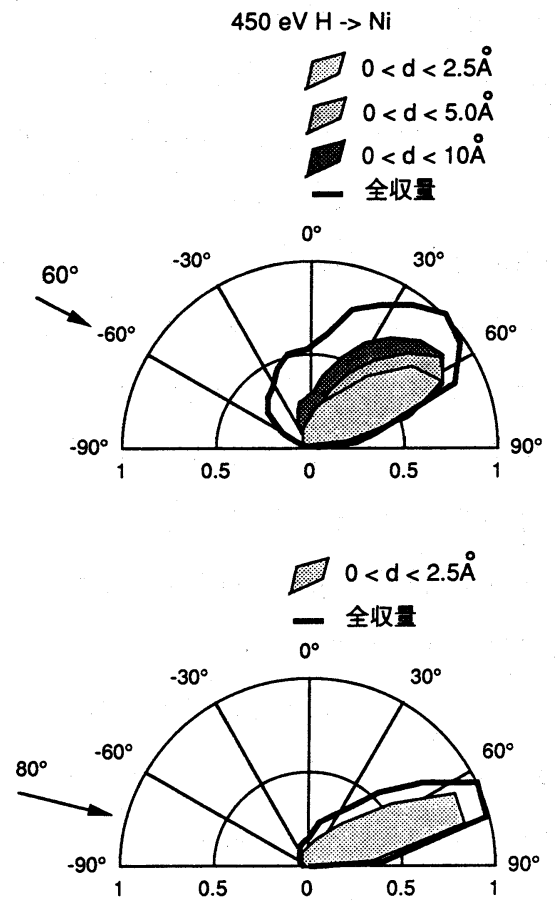

図14. $450 \mathrm{eVH}^{+} \rightarrow \mathrm{Ni}\left(\theta=60^{\circ}, 80^{\circ}\right)$ の角度分布に おけるはじきだし過程とランダム過程の寄与。 ACAT シミュレーション $(\mathrm{Kr}-\mathrm{C}, a=0.100 \AA)$ の 結果. 
が予想される。表面に発達したトポグラフィ，すなわ ち，表面の粗さをシミュレーションに取り入れる方法は いろいろ提案されているが定量的，一般的な取り扱いは 困難である。表面の粗さの角度分布への影響は，まず， 隣の原子による遮蔽効果が弱まり優先放出角がより小さ くなることが考えられる。また，収量が減少することも 考えられる.しかしながら， $E=450 \mathrm{eV}$ で $\theta=80^{\circ}$ の場 合に限って言えば，直接はじきだし過程の理論による優 先放出角（この理論には隣の原子による遮蔽効果は含ま れていない) とシミュレーションの優先放出角が完全に 一致していることから，隣の原子による遮蔽効果によっ てよって実験とシミュレーションの分布が一致しないと は言えない。

闵12，13，14からもわかるようにシミュレーションの 優先放出角は用いた 2 体間ポテンシャルに関係せず，ほ ぼ， $70^{\circ}$ であり理論值 $72^{\circ}$ と良く一致している。間接は じきだし過程による優先放出角は理論的に言って直接は じきだし過程による優先放出角より大きいはずである。

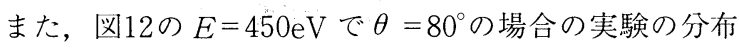
の特徵は分布の巾が比較的広いこと, そして, 後方にス パッターされた原子がかなり存在することである。この

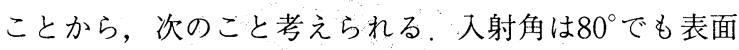
の粗さのため, 図16に示すように実質的にはいろいろな 角で表面を吒いている可能性がある。そこで，例えば， 図17に示すように入射角に分布を持たすことよって，こ こでは, 粗さは $\left(\Delta_{1} / \Delta_{2}\right)$ で特徴づけているが, 表面 の粗さをシミュレーションすることも可能である。その 結果は図18に示した。ここに，ポテンシャルは $\mathrm{Zr}-\mathrm{C}(a$ $=0.100 \AA)$ で, 図における random surface というのは

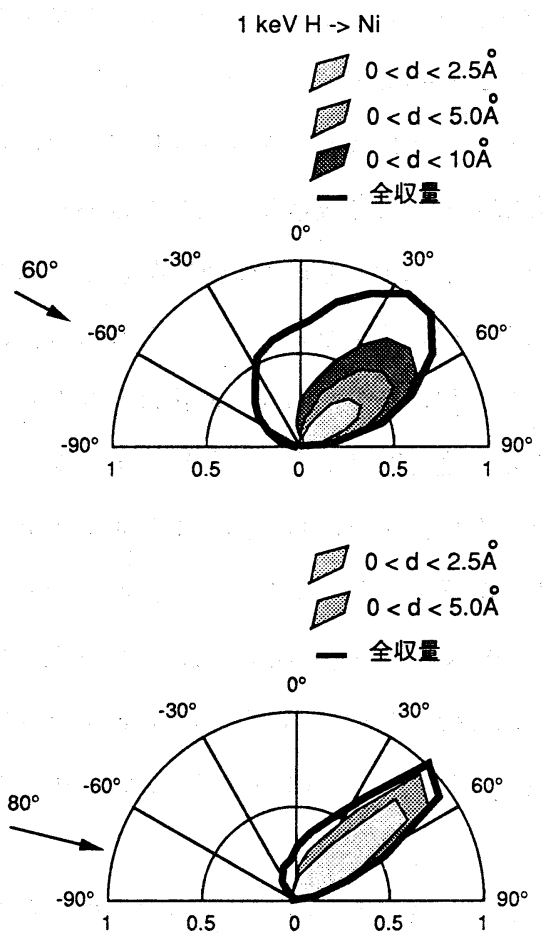

図15. $1 \mathrm{keVH}^{+} \rightarrow \mathrm{Ni}\left(\theta=60^{\circ}, 80^{\circ}\right)$ の角度 分布におけるはじきだし過程とランダ ム過程の寄与. ACAT シミュレーション $(\mathrm{Kr}-\mathrm{C}, a=0.100 \AA)$ の結果.

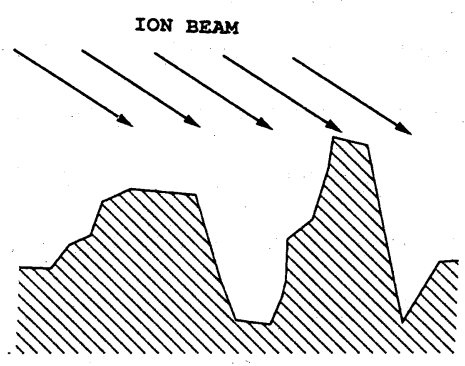

図16. 表面粗さの模式図.

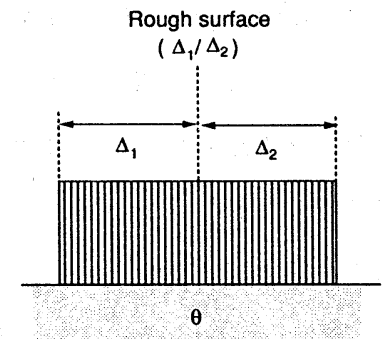

図17. 表面粗さを考慮した入射イオンビームの 角度の広がり。 
図 5 にあるACAT 表面のことである rough

$450 \mathrm{eV} \mathrm{H} \rightarrow \mathrm{Ni}$

- ACAT (random surface)

- ACAT-rough $\left(40^{\circ} / 5^{\circ}\right)$

○ Experiment

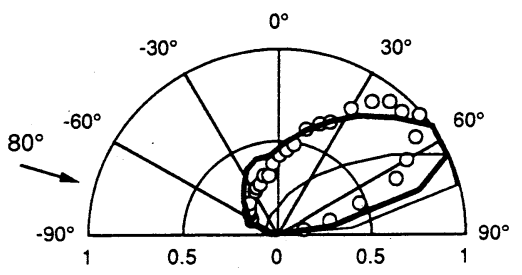

図18. 表面粗さを考慮した場合の $450 \mathrm{eVH}^{+} \rightarrow \mathrm{Ni}$ $\left(\theta=80^{\circ}\right)$ の角度分布.

\section{4. まとめ}

イオンとしては軽水素, 標的物質としては $\mathrm{Ni}$ を選び, 軽イオンスパッタリング収量の入射角依存性とス パッター原子の解度分布をモンテカルロ・シミュレーションコードACAT と簡単なはじきだしモデルを用い て計算し，実験と比較検討した。入射エネルギーとしては $450 \mathrm{eV}$ と $1 \mathrm{keV}$ 用いた。

軽イオンが斜めに照射された場合のスパッタリング現象の主たる様相ははじきだし過程で説明できる。は じきだし過程には直接過程と間接過程があり，入射角が小さいに場合には間接はじきだし過程しか起こりえ ず，大きい場合には直接はじきだし過程が主である。本報告でのイオンのエネルギーは比較的低いので数值 計算することにより，はじきだし過程による角度分布やその優先放出角を求めた。

スパッタリング収量の入射角依存性については 2 体間ポテンシャルを適切に選べば実験を再現できること がわかった，直接はじきだしモデルによる侮度分布は非常にはっきりした優先放出解を持ち，その理論値は $1 \mathrm{keV}$ の場合, シミュレーションの值, 実験值とよい一致をみた。しかしながら, 低エネルギーですれすれ 秹で照射した場合はスパッタリングは表面第一層でしか起こっていなくて現実の角度分布は表面荒さに強く の影響されていることがわかった。

\section{参考文献}

1) R. Weissmann and R. Behrisch : Rad. Eff. 19 (1973) 69.

2) U. Littmark and S. Fedder : Nucl. Instr. Meth. 194 (1982) 607.

3) Y. Yamamura, N. Matsinami and N. Itoh : Rad. Eff. 71 (1983) 65.

4) P. Sigmund: Phys. Rev. 184 (1969) 383.

5) Y. Yamamura, Y. Itikawa and N. Itoh: IPPJ-AM-26, Institute of Plasma Physics, Nagoya Univ. (1983).

6) G.K. Wehner: J. Appl. Phys. 30 (1959) 1762.

7) H.L. Bay and J. Bohdansky: Appl. Phys. 19 (1979) 421.

8) J. Bohdansky, G. L. Chen, W. Eckstein, J. Roth and B.M. U. Scherzer, J. Nucl. Mater. 111\&112 (1982) 717.

9) J. Roth, J. Bohdansky and W. Ottenberger : IPP $9 / 26$ (1979).

10) A. A. Haars, J.W. Davis and C.H. Wu : J. Nucl. Mater. 162-164 (1989) 915

11) J. Roth, J. Bohdansky and W. Ottenberger: J. Nucl. Mater. 165 (1989) 193.

12) Y. Yamamura and K. Muraoka, Nucl. Instr. Meth. B42 (1989) 175.

13) M. Vicanek, J. J. Jimenz Rodriguez and P. Sigmund : Nucl. Instr. Meth. B36 (1989) 124. 
14) W. Eckstein and J.P. Biersack: Appl. Phys. A37 (1985) 95.

15) Y. Yamamura, C. Mossner and H. Ochsner : Rad. Eff. 103 (1987) 25.

16) Y. Yamamura and T. Takiguchi : Rad. Eff. Def. in Solids (to be published).

17) T. Okutani and R. Shimizu, Jpn J. Appl. Phys. 21 (1982) 570.

18) H.L. Bay, J. Bohdansky, W. O. Hofer and J. Roth: Appl. Phys. 21 (1980) 327.

19) J. Bohdansky, G.L. Chen, W. Eckstein and J. Roth : J. Nucl. Mater. 103\&104 (1981) 339.

20) H.L. Bay and W. Berres, Nucl, Instr. Meth. B2 (1984) 606.

21) W. Berres, D. Rusbuldt, E. Hintz and H.L. Bay: Appl. Phys. B35 (1984) 83.

22) Y. Yamamura, Nucl. Instr. Meth. 230 (1984) 578.

23) Y. Yamamura:: Rad. Eff. 80 (1984) 193.

24) W. Eckstein and J.P. Biersack : Nucl. Instr. Math, B7/8 (1984) 727.

25) W, Eckstein : IPP-Report, No. 58, Garching (1986).

26) Y. Yamamura, C. Mossner and H. Ochsner : Rad. Eff. 105, (1987) 31. 